\title{
Uniformity of Cool Air Discharge along a Perforated Tube for Zone Cooling in a Greenhouse
}

\author{
Herry Suhardiyanto and Takahisa Matsuoka \\ Faculty of Agriculture, Kochi University, Nankoku 783, Japan
}

(Received December 16, 1992)

\begin{abstract}
Experimental and theoretical investigations were conducted to evaluate the uniformity of cool air discharge along a perforated distribution tube for zone cooling in a greenhouse. The calculated static pressures in the tube agreed well with the experimental results. Air temperature in the tube was calculated by considering a constant overall heat flux through the tube wall along the tube length. A good agreement was obtained between the calculated and measured air temperatures in the tube. The coupled analysis of air flow and heat transfer was used to simulate the uniformity of cool air discharge for practical input variables. Furthermore, the relationships between the uniformity of cool air discharge and the design parameters of the tube were obtained.
\end{abstract}

\section{INTRODUCTION}

A zone cooling system has been suggested as an energy efficient cooling method for greenhouses. This method has been suggested to cool only the environment surrounding the greenhouse plants rather than the entire enclosed greenhouse air. ${ }^{1-4)}$ To increase the cooling efficiency, the zone cooling system was equipped with perforated polyethylene tubes for cool air distribution. ${ }^{4}$

The discharge flow rate from perforated air distribution tubes has been studied by a number of researchers. ${ }^{5-7)}$ However, the temperature distribution along the tube length, which is a major concern in designing a perforated tube for cool air distribution has not been studied previously. The present study was conducted to evaluate the uniformities of discharge flow rate and air temperature along a cool air distribution tube for zone cooling in a greenhouse.

\section{EXPERIMENTAL PROCEDURE}

The experimental zone cooling system: Two spot coolers (Hitachi Reinetsu Corp., SR-40GLT1) were used to provide cool air. The cool air was drawn into a perforated tube by means of a vane-axial fan. Two types of perforated tube were tested in this study. The perforated tubes with different hole spacing were made from tubular polyethylene film, $10 \mathrm{~m}$ in length and $23.2 \mathrm{~cm}$ in diameter. However, the total length of each tubular film was $15 \mathrm{~m}$, that was including non-perforated sections of $4.5 \mathrm{~m}$ long in the upstream and $0.5 \mathrm{~m}$ long in the downstream of the perforated section. The downstream ends of the tubes were sealed tightly. Discharge holes were located at both the tube sides. The design of the tested tubes and the inlet flow rate used in the experiment are given in Table 1. When the perforated tube was tested, the tube was suspended to reduce vibrations and to maintain the tube in horizontal and straight condition. Furthermore, the tube was protected from direct solar radiation 
Table 1 The design of perforated tubes and the inlet flow rate used in the experiment.

\begin{tabular}{cccccccccc}
\hline $\begin{array}{c}\text { Exp. } \\
\text { No. }\end{array}$ & $\begin{array}{c}\text { Tube } \\
\text { diam. } \\
(\mathrm{cm})\end{array}$ & $\begin{array}{c}\text { Tube } \\
\begin{array}{c}\text { (ength } \\
(\mathrm{m})\end{array}\end{array}$ & $\begin{array}{c}\text { Hole } \\
\text { diam. } \\
(\mathrm{cm})\end{array}$ & $\begin{array}{c}\text { Hole } \\
\text { spacing } \\
(\mathrm{cm})\end{array}$ & $\begin{array}{c}\text { Number } \\
\text { of } \\
\text { disch. } \\
\text { station }\end{array}$ & $\begin{array}{c}\text { Area } \\
\text { ratio }^{z}\end{array}$ & $\begin{array}{c}\text { Inlet } \\
\text { flow rate } \\
\left(\mathrm{m}^{3} \cdot \mathrm{sec}^{-1}\right)\end{array}$ & $\begin{array}{c}\text { Pressure at } \\
\text { upstream end }\end{array}$ \\
\hline 1 & 23.2 & 10 & 1.25 & 10.0 & 101 & 0.59 & 0.168 & 64.7 & $\begin{array}{c}h^{\mathrm{y}} \\
(\mathrm{Pa})\end{array}$ \\
\hline 2 & 23.2 & 10 & 1.25 & 10.0 & 101 & 0.59 & 0.148 & 50.6 & 58.2 \\
3 & 23.2 & 10 & 1.25 & 6.7 & 151 & 0.88 & 0.168 & 30.0 & 40.1 \\
4 & 23.2 & 10 & 1.25 & 6.7 & 151 & 0.88 & 0.148 & 23.3 & 30.9 \\
\hline
\end{tabular}

z Area ratio $=$ total area of discharge holes divided by cross-sectional area of the tube.

y $h=$ static pressure.

and reflected radiation from soil surface by means of styrofoam boards.

Measurements: Before conducting measurements, a maximum design value for total pressure at the discharge station was determined to meet the maximum air velocity of $1.0 \mathrm{~m} \cdot \mathrm{sec}^{-1}$ in the plant zone. ${ }^{8)}$ Velocity measurements were conducted at a distance of $50 \mathrm{~cm}$ from the tube wall using an anemometer (Rion Co., Ltd., AM-10). The tested flow rates as given in Table 1 were within the maximum design value for total pressure.

A digital micro manometer (precision $= \pm 0.01 \mathrm{~mm} \mathrm{H}_{2} \mathrm{O}$, Okano Works Ltd., DP-10A), which was connected to a pitot tube, was used to measure static pressures at 11 discharge stations in $1 \mathrm{~m}$ spacing along the tube length. A discharge station is defined as a position in the center line of the tube between a pair of diametrically opposing holes. Data were scanned every second and were averaged every period of 3 min using a data logger (Takeda Riken Co., Ltd., TR 2723). The inlet flow rate was obtained from velocity pressure data measured according to JIS.

Air temperatures inside the tube were measured at 11 discharge stations as same as pressure measurements. Copper-constantan thermocouples (diameters $=0.32$ $\mathrm{mm}$ ) were used for temperature measurements. To reduce errors in temperature measurements that may caused by solar radiation, shading shelters were applied to all temperature sensors. Temperature data were scanned and averaged together with the pressure data using the same logger. Measurements were conducted in sunny days in the late summer of 1992.

\section{ANALYSIS}

Analysis of air flow: The following assumptions were made: (1) the air flow in the tube was steady and uncompressed, (2) the change in density of air along the perforated tube due to the change in its temperature was negligible, (3) the perforated

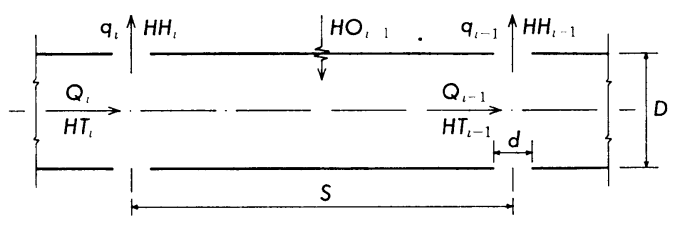

Fig. 1 A schematic diagram of air flow and heat transfer in the perforated tube. tube was horizontally straight.

Figure 1 illustrates a tube section between two successive discharge stations and some variables used in the analysis. In the following equations, the subscript $i$ denotes the discharge station number or the tube section number starting from 
the downstream end of the tube.

The equation of flow continuity for each tube section between two successive discharge stations is given by

$$
Q_{i}-q_{i}-Q_{i-1}=0
$$

where, $Q_{i}$ and $Q_{i-1}$ are the air flow rate $\left(\mathrm{m}^{3} \cdot \mathrm{sec}^{-1}\right)$ in the tube sections $i$ and $i-1$, respectively, $q_{i}$ is the discharge flow rate from a pair of holes at the discharge station $i$.

The flow rate of air discharged from a pair of holes at the discharge station $i$ is written as $^{9)}$

$$
q_{i}=2 C d_{i} \cdot A \sqrt{2 E_{i} \cdot G c / \rho}
$$

where, $C d_{i}$ is the coefficient of discharge for air flow through the discharge holes, $A$ is the area of one hole $\left(\mathrm{m}^{2}\right), E_{i}$ is the total pressure at the discharge station $(\mathrm{Pa}), G c$ is the universal conversion factor $=1.0 \mathrm{~kg} \cdot \mathrm{m} \cdot \mathrm{N}^{-1} \cdot \mathrm{sec}^{-2}, \rho$ is the air density $\left(\mathrm{kg} \cdot \mathrm{m}^{-3}\right)$. Because the discharge direction is not always perpendicular to the plane of discharge hole along the tube length, $E_{i}$ is used in Eq. (2) to account for the change in the discharge direction.

It has been known that the coefficient of discharge varies according to several variables. However, the ratio of velocity pressure to total pressure at the discharge station has been recognized as the most important variable affecting the coefficient of discharge. ${ }^{9,10)}$ The coefficient of discharge is not constant along the tube, but decreases as the velocity pressure becomes a larger part of the total pressure. The coefficient of discharge may be determined from the following empirical relationship ${ }^{10)}$

$$
C d_{i}=0.675-0.455 \alpha_{i}+0.716 \alpha_{i}{ }^{2}-0.936 \alpha_{i}{ }^{3}
$$

where, $\alpha_{i}=\rho \cdot V_{i}^{2} /\left(2 E_{i}\right), V_{i}$ is the mean air velocity $\left(\mathrm{m} \cdot \mathrm{sec}^{-1}\right)$ inside the tube at the discharge station.

The friction loss in tube sections between two successive holes is given by the Darcy-Weisbach equation as follows:

$$
P_{i}=\lambda_{i} \cdot \rho \cdot V_{i}{ }^{2} \cdot S /(2 D)
$$

where, $P_{i}$ is the friction loss in the tube section $(\mathrm{Pa}), \lambda_{i}$ is the friction coefficient in the tube section, $S$ is the length of the tube section=hole spacing $(\mathrm{m}), D$ is the diameter of the tube $(\mathrm{m})$. The friction coefficient in the tube section can be determined by the equation of Poiseuille (Eq. (5)) and the empirical relationship of Blasius (Eq. (6)) for smooth pipe. ${ }^{11)}$

$$
\begin{array}{ll}
\lambda_{i}=64 / R e_{i}, & \text { for } R e_{i}<2000 \\
\lambda_{i}=0.316 /\left(R e_{i}\right)^{0.25}, & \text { for } 2000 \leq R e_{i}<100000
\end{array}
$$

where, $R e_{i}$ is the Reynolds number for air flow in the tube section.

The total pressure at discharge station No. $i+1$ may be calculated using the following relationship:

$$
E_{i+1}=E_{i}+P_{i} .
$$

To determine the discharge flow rate from all discharge stations along the tube length, the calculations can be started from the downstream end of the tube. ${ }^{10,12)}$ 
Air flow at the remaining length of tube downstream of discharge station No. 1 is zero. For small values of $q$, the air velocities in the tube upstream and downstream of a discharge station are approximately equal. Therefore, it is reasonable to use the downstream velocity $\left(V_{i-1}\right)$ in calculating the velocity pressure rather than using the upstream velocity $\left(V_{i}\right){ }^{9)}$ Thus, $C d_{1}$ can be determined using Eq. (3). To start the calculations, an initial value of total pressure has to be made for discharge station No. 1. Calculations for upstream discharge holes are defined by using Eqs. (1) to (7) in order with successively increasing subscripts.

Analysis of heat transfer: It was assumed that: (1) the effect of solar radiation on air temperature inside the tube was negligible, (2) air temperature inside the tube varied linearly along the tube section between two successive discharge stations.

The following steady-state heat balance is given for each tube section between two successive discharge stations as illustrated in Fig. 1:

$$
H T_{i}-H H_{i}+H O_{i-1}-H T_{i-1}=0
$$

where, $H T_{i}$ is the heat rate of air flow in the tube, $H H_{i}$ is the heat rate of air discharged from a pair of holes, $\mathrm{HO}_{i-1}$ is the overall heat transfer rate through the tube wall. The dimension used for the heat flows in Eq. (8) is watt. As it appears in analysis of air flow, subscript $i$ refers to the discharge hole number or the tube section number.

The $H T_{i}$ and $H H_{i}$ values are given by Eqs. (9) and (10), respectively.

$$
\begin{aligned}
& H T_{i}=Q_{i} \cdot \rho \cdot C p \cdot T_{i} \\
& H H_{i}=q_{i} \cdot \rho \cdot C p \cdot T_{i}
\end{aligned}
$$

where, $C p$ is the specific heat of air $\left(\mathrm{J} \cdot \mathrm{kg}^{-1} \cdot{ }^{\circ} \mathrm{C}^{-1}\right), T_{i}$ is the temperature of air flow in the tube $\left({ }^{\circ} \mathrm{C}\right)$.

The values of $Q_{i}$ and $q_{i}$ along the tube length can be determined using Eqs. (1) to (7). Therefore, if it is desired to calculate the $T_{i}$ value for all discharge stations, the $\mathrm{HO}_{i}$ value must be given for all tube sections.

Uniformities of discharge flow rate and air temperature: The uniformity of discharge flow rate along the perforated tube is defined by

$$
U q=100\left(1-\sum_{i=1}^{n}\left|\bar{q}-q_{i}\right| /(n \cdot \bar{q})\right)
$$

where, $U q$ is the uniformity of discharge flow rate $(\%), \bar{q}$ is the average value of $q_{i}$, $n$ is the total number of the discharge stations. The uniformity of air temperature in the tube may be calculated using the relationship given in Eq. (11) by replacing $q$ with $T$.

\section{RESULTS}

\section{Measured and calculated static pressures}

To validate the method for calculating the discharge flow rate as described in the analysis, the calculated static pressure values were compared with the measured values. Figure 2 shows the comparison of calculated and measured static pressures. Lines indicate the calculated static pressures along the tube length and symbols refer to the static pressures measured at 11 discharge stations. In this calculation, the 

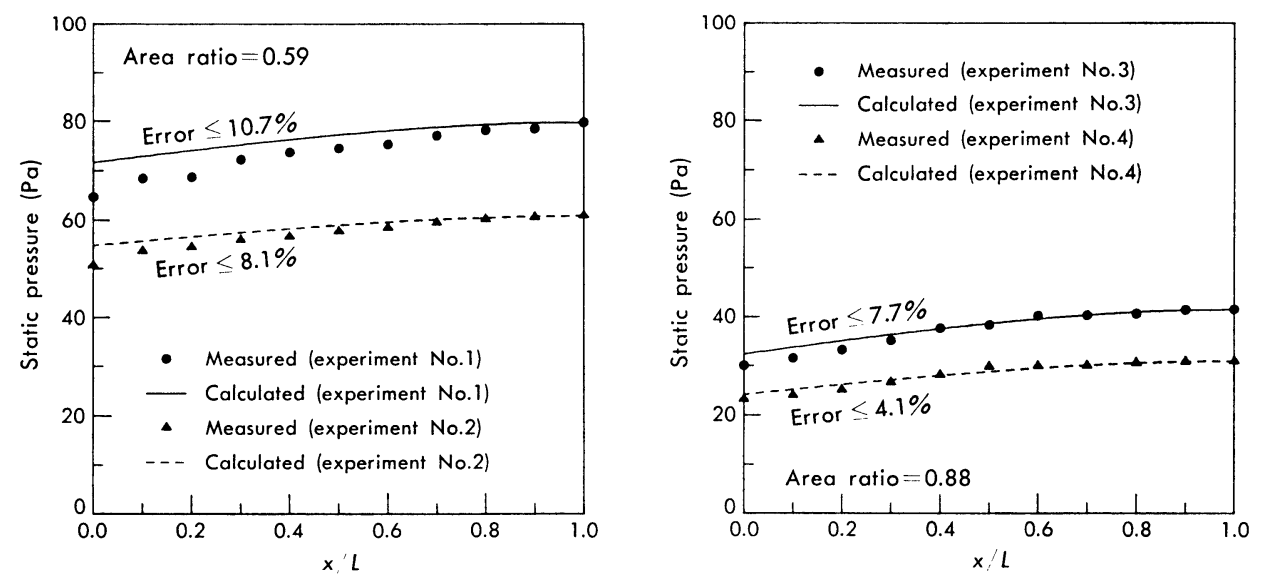

Fig. 2 Measured and calculated static pressures along the perforated tube.

measured values for the downstream end $(x / L=1)$ were used as the input variables where, $x$ was the distance from discharge station No. $n$ to the downstream and $L$ was the length of the perforated section of the tube. The error in the calculated static pressure was defined as the ratio of the difference between the calculated and measured values to the measured value. The ranges of error in the calculated static pressure are indicated in Fig. 2.

\section{Air temperature in the tube}

Typical measurement results of air temperature in the tube are shown in Fig. 3. Circles and triangles are the afternoon and the evening data, respectively. The trends of increasing air temperature with $x / L$ for the tested tubes were similar. For these tubes, from $x / L=0.0$ to $x / L=0.8$, the increase in air temperature was lower than $1{ }^{\circ} \mathrm{C} \cdot \mathrm{m}^{-1}$ in the afternoon and in the evening. However, in the last $10 \%$ of the tube length, it increased to about $3-6^{\circ} \mathrm{C} \cdot \mathrm{m}^{-1}$ and $2-3^{\circ} \mathrm{C} \cdot \mathrm{m}^{-1}$ in the afternoon and in the evening, respectively.

It was tried to simplify the analysis of heat transfer by representing convective
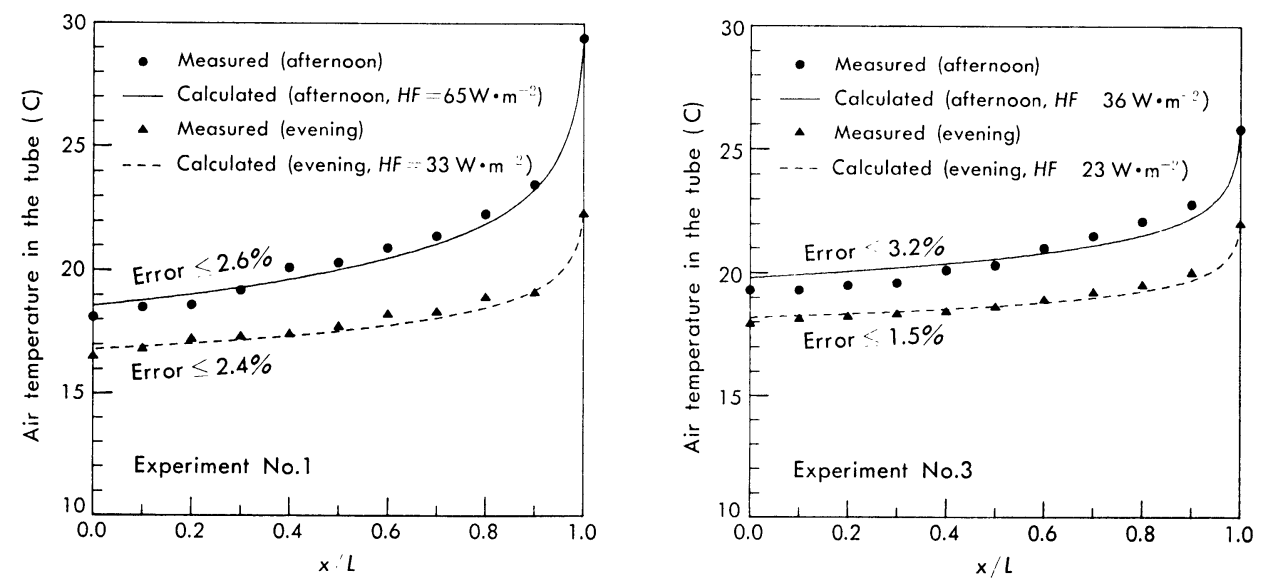

Fig. 3 Measured and calculated air temperatures along the perforated tube. 
and radiative heat transfers through the tube wall in a single term of heat flux $(H F)$. Furthermore, the $H F$ value was considered to be constant along the tube length. The results of temperature measurement were used to search the $H F$ value iteratively. Lines in Fig. 3 show the calculated air temperature along the tube length. The calculated results indicated a bit deviation from the measured values. The error in the calculated air temperature was defined in the same way as the error in the calculated static pressure was defined. The ranges of error in the calculated air temperature are indicated in Fig. 3.

\section{Simulation of cool air discharge}

Uniformity of cool air discharge may be described by the uniformity in discharge flow rate and the uniformity of air temperature in the tube. Simulation of these two components of uniformity of cool air discharge was conducted using Eqs. (1) to (11). The input variables used in the simulation are given in Table 2. Figure 4 shows the distribution of discharge flow rate along the tube length for three area ratios.

Table 2 Input variables for simulations of discharge flow rate and air temperature.

\begin{tabular}{lc}
\hline \multicolumn{1}{c}{ Variables } & $\begin{array}{c}\text { Values } \\
\text { used }\end{array}$ \\
\hline Tube length $(\mathrm{m})$ & 10 \\
Tube diameter $(\mathrm{cm})$ & 23.2 \\
Hole diameter $(\mathrm{cm})$ & 1.25 \\
Area ratio & $0.4-1.4$ \\
Total pressure at downstream end $(\mathrm{Pa})$ & 80 \\
Air temperature at downstream end $\left({ }^{\circ} \mathrm{C}\right)$ & 25 \\
$H F=$ Overall heat flux through tube & \\
wall $\left(\mathrm{W} \cdot \mathrm{m}^{-2}\right)$ & $20-70$ \\
\hline
\end{tabular}

z See the footnote of Table 1 .
Figure 5 shows the effect of area ratio on the uniformity of discharge flow rate and Euler number at the upstream end of the tube. The trends in the increase of air temperature in the direction of cool air flow are presented in Fig. 6 for three $H F$ values. Figure 7 shows how the uniformity of air temperature in the tube increases as the $H F$ value is reduced. In addition, it was noted that the area ratio has no considerable effect on the uniformity of air temperature in the tube.

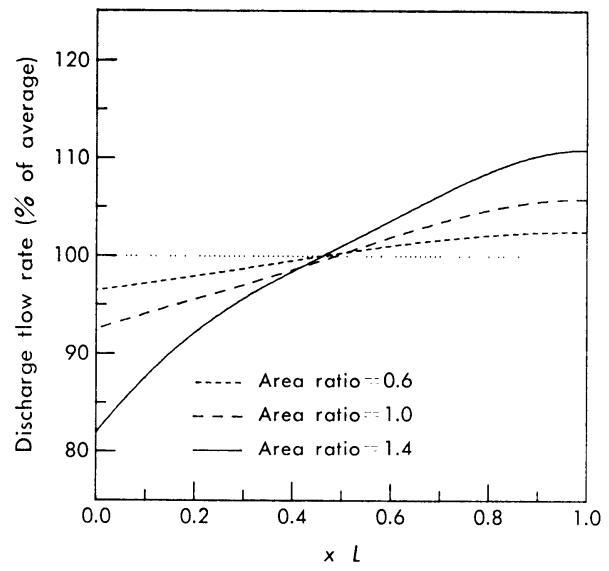

Fig. 4 Simulated discharge flow rate (percent of average) along the perforated tube.

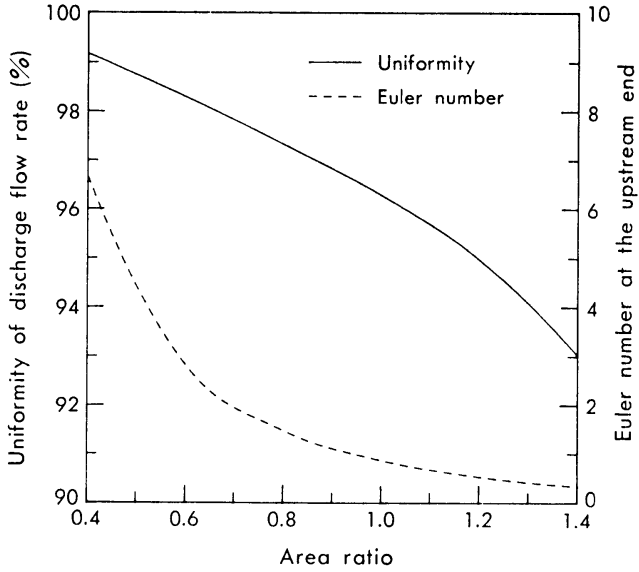

Fig. 5 Effect of area ratio on the uniformity of discharge flow rate and Euler number at the upstream end of the tube. 


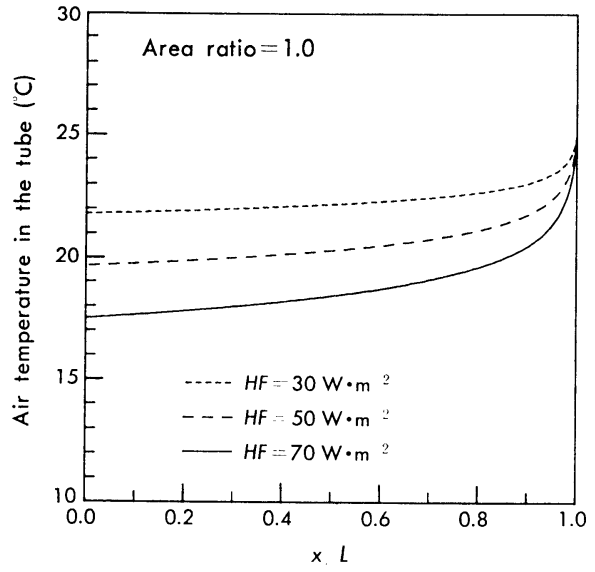

Fig. 6 Simulated air temperature along the perforated tube.

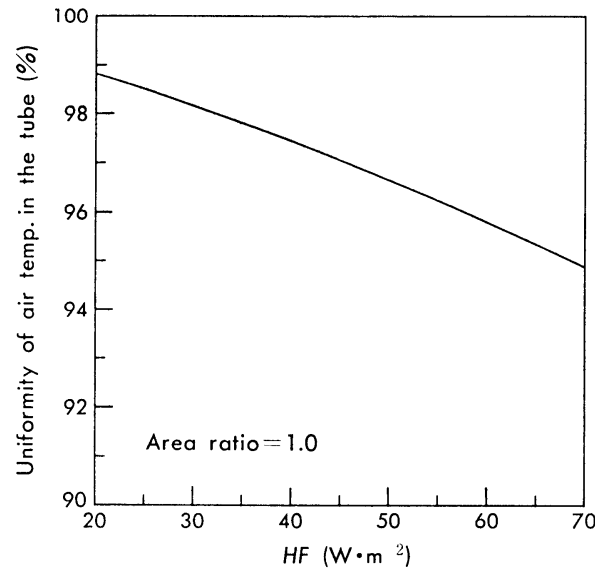

Fig. 7 Effect of a constant $H F$ along the perforated tube on the uniformity of air temperature in the tube.

\section{DISCUSSION}

Figure 2 shows that the static pressures calculated using Eqs. (1) to (7) were in a reasonable agreement with the measured values. The static pressure value dominated in determining the total pressure value and therefore the discharge flow rate. Therefore, the analysis of air flow may be coupled with the analysis of heat transfer to calculate air temperature along the length of a perforated tube.

In calculating air temperature in the tube by considering a constant $H F$ along the tube length, the errors occurred within $3.2 \%$ (Fig. 3). The results point out the benefit of the consideration of a constant $H F$ along the tube length. This method may be used as a design tool to predict air temperature in the tube with adequate accuracy.

An improvement in the uniformity of discharge flow rate $(U q)$ can be obtained by reducing the ratio of total area of discharge holes to cross-sectional area of the tube (Figs. 4 and 5). The improvement in $U q$ value by reducing the area ratio is accompanied by an increase in Euler number at the upstream end of the tube $(E u)$. It means that this improvement of uniformity causes a larger static pressure at the upstream end of the tube for a given inlet flow rate. As the area ratio decreases below 0.6 , the $E u$ value increases rapidly (Fig. 5).

In the last $10 \%$ of the tube length, as the flow of cool air approaches the downstream end (its velocity approaches to zero), the heat rate of air flow in the tube decreases rapidly. On the other hand, the overall heat gain through the tube wall remains constant. As a result, the air temperature in that tube section increases rapidly (Fig. 6). Furthermore, the uniformity of air temperature in the tube decreases as the overall heat flux through the tube wall increase (Fig. 7).

These characteristics seem to occur in this type of cool air distribution tube. Therefore, in designing a greenhouse zone cooling system with perforated tubes for cool air distribution, it is suggested to consider these phenomena. 


\title{
REFERENCES
}

1) Kojima, K. and H. Suhardiyanto. 1991. Studies on the zone cooling system in greenhouse (1) Performance of the system in a model-sized greenhouse. Environ. Control in Biol. 29: 110.

2) Kojima, K., T. Matsuoka, and H. Suhardiyanto. 1991. Performance of zone cooling system in greenhouse: An evaluation of experimental factors. In "Mathematical and Control Applications in Agriculture and Horticulture" (Ed. by Hashimoto, Y. and W. Day) 51-56, Pergamon Press, Oxford.

3) Cho, I. H., H. Nishina, M. Tanaka, and Y. Hashimoto. 1992. Zone cooling in greenhouse in the daytime in summer, including relation to blossom-end rot of tomato plants. SHITA J. 4: 30-39.

4) Suhardiyanto, H. and T. Matsuoka. 1992. Studies on a zone cooling system in a greenhouse (2) Evaluation of a system for microclimate modification in a plastic greenhouse during hot weather. Environ. Control in Biol. 30: 143-151.

5) Carpenter, G. A. 1972. The design of permeable ducts and their application to the ventilation of livestock buildings. J. Agric. Eng. Res. 17: 219-230.

6) Saunders, D. D. and L. D. Albright. 1984. Airflow from perforated polyethylene tubes. Trans. ASAE 27: 1144-1149.

7) Small, D. 1989. Performance of a perforated plastic ventilation duct. ASAE/CSAE Paper No. 89-4068. ASAE, St. Joseph, MI 49085.

8) ASAE Engineering Practice: ASAE EP 406.1. 1990. Heating, ventilating and cooling greenhouses. ASAE, St. Joseph, MI 49085.

9) Rawn, A. M., F. R. Bowerman, and N. H. Brooks. 1960. Diffusers for disposal of sewage in sea water. Proc. ASCE J. Sanit. Eng. Div. 86(3): 65-105.

10) Vigander, S., R. A. Elder, and N. H. Brooks. 1970. Internal hydraulics of thermal discharge diffusers. Proc. ASCE J. Hydraul. Div. 96: 509-527.

11) Rouse, H. 1946. "Elementary Mechanics of Fluids"' 202-203, John Wiley \& Sons, New York.

12) Davis, D. C., J. S. Romberger, C. A. Pettibone, S. C. Andales, and H. J. Yeh. 1980. Mathematical model for air flow from perforated circular ducts with annular corrugations. Trans. ASAE 23: 661-666.

\section{〈和文抄錄〉}

\author{
グリーンハウス内の局所冷房用孔開きチューブの流れ方向の冷気排出の均等性 \\ ヘリー スハルディヤント・松岡孝尚 \\ 高知大学農学部
}

孔開きポリエチレンチューブを用いたグリーンハウス内の局所冷房装置の設計や操作の基礎資料を得 ることを目的として，流れ方向の空気の排出特性および温度分布特性について，実験と理論により考察 したチューブ内静圧について実測值と計算值はよい一致を示した．また，チューブ壁からの侵入熱量 （熱通過）を流れ方向に一定として計算した結果，実測温度と計算值は一致した。さらに，チューブ内 空気の流れと熱移動の解析を組み合わせてシミュレーションを行い，流れ方向における排出空気量の分 布および温度分布の均等性の条件を明らかにし, 温度分布の予測を可能にした. また, 設計条件として 重要な因子である面積比，オイラー数，熱通過と冷風排出の均等性の関係を示した. 